\title{
Performance of Broiler Finisher Placed on Different Levels of Pro-Vitamin a Cassava-Based Diet
}

\author{
*E. C. Ogundu, H. E. Akpan, J. S. Ekpo, I. S. Meme \\ Department of Animal Science, Akwalbom State University, ObioAkpa Campus, Nigeria
}

\begin{abstract}
This experiment was carried out to determine the performance of broiler finisher placed on different levels of inclusion of pro-vitamin A cassava-based diet (0\%, 25\%, 50\%, 75\% and 100\%) using maize-based diet as control. The results show that the daily weight gain of birds placed on $0 \%$ was statistically $(p<0.05)$ higher than those on $100 \%$ but not on those of $25 \%, 50 \%$, and $75 \%$. However the birds placed on $100 \%$ level had the lowest growth ratewhich was significantly $(p<0.05)$ different from birds on $0 \%$ and $25 \%$ but not with birds on $50 \%$ and $75 \%$. The average daily feed intake did not show any significant difference ( $p>0.05$ )among all the diets. The feed conversion ratio was not statistically $(p>0.05)$ different from one another. The cost of production was highest with maize-based diet (0\%) while that of the $75 \%$ and $100 \%$ were the cheapest with cost reduction of $34.19 \%$ and $40.46 \%$ per birdrespectively. The lower cost of production with pro-vitamin A cassava compensates the growth rate suggesting that pro-vitamin A cassava-based diet can totally replace maize-based diet in broiler diets without any deleterious effect when properly processed to reduce the cyanogenic content of the cassava to non-toxic level
\end{abstract}

Keywords: Broiler finisher, Performance, Pro-vitamin A cassava,

\section{Introduction}

Biofortification of staple crops with pro vitamin A carotenoid is an emerging strategy to address the vitamin A status of the poor and improve animal feed (Tanumihardjoet al 2008)[1]Cassava, (Manihotesculentacrantz), a tropical root crop is Africa's second most important staple food after maize in terms of calories consumed. Nigeria is the largest producing country in the world with estimated production of 34 million tons in 2002. (FAO, 2003) [2]. It is a source of calories for about 500,000 million people in the tropics and its use as animal feed component is increasing (Julie et al 2009)[3].

Cassava is a major target for Biofortification. The Bill and Melinda Gates foundation since 2005 has supported a global efforts to develop cassava germplasm enriched with bioavailable nutrients, (Bio cassava plus $2005 \mathrm{http}: / /$ bio cassavaplus.org)[4]. This initiative is called Bio cassava plus and has the following major objectives: to increase the minerals, zinc, iron, protein, vitamin A and E, decrease cyanogen content, delay post harvest deterioration and develop virus-resistant varieties. (Julie et al 2009)[3].

In a bid to enhance the nutritive qualities of cassava through the supply of pro-vitamin A with low cyanogenic potentials, six (6) elite new yellow and white cassava varieties have been developed in National Root Crop Research Institute, Umudike, Umuahia, Nigeria (Eleazu and Eleazu 2012)[5].In poultry production the cost of feed accounts for up to $80 \%$ of the total cost and is an important component in determining the extent of poultry survival and profitability (Olugbemiet al 2010)[6].Maize has been playing a major role as a major source of energy in poultry diets in Nigeria and because it is one of the major staple foods as well as its use for various industrial raw materials, its demand is more than its supply, leading to increase in its price, high cost of poultry feed production and animal products (Enyenihiet al 2009)[7]. Over the last four decades there has been growing interest in cassava cultivation and utilization in animal nutrition as an alternative feedstuff to maize. Researches have shown that different animals can tolerate different levels of cassava root meal in relation to reference diets without any deleterious effect. (Omole and Eshiet 1976,[8]. Reveron and Rodriguez 1982.[9] Tulemet al 2005. [10].

Cassava contains the Cyanogenicglucoside, Linamarin and Lotaustralin which are hydrolyzed to hydrogen cyanide by endogenous linamarase on tissue damage. (Conn, 1981).[11]. Its growing use as food and animal feed could be hampered by the presence of these toxic cyanogens in the tubers (Ikediobiet al 1980),[12]. However, different cassava processing methods especially sun drying have been found to reduce the cyanide content to levels that will not be of adverse effect to the animals (Tewe and Egbunike 1992,[13],Eleazu and Eleazu2012,[5],Chioma and Ogundu 2009,[14],Ogunduet al 2014, [15]).

The objective of this experiment therefore is to use pro-vitamin A cassava to replace maize at different levels of inclusion and to determine at what level that will compare favorably with reference maize-based diet in the performance of broiler finishers such as average daily weight gain, feed intake and feed conversion ratio and economic effectiveness in relation to the reference maize-based diet. 


\subsection{Location of study}

\section{Materials And Methods}

The experiment was carried out at the poultry unit of the AkwaIbom State University, ObioAkpa Campus, AkwaIbom State, Nigeria, located between latitude $4^{\circ} 32^{\prime} \mathrm{N}$ and $5^{\circ} 33^{\prime} \mathrm{N}$ and longitude $7^{\circ} 25^{\prime} \mathrm{E}$ and $8^{\circ} 25 /$ $\mathrm{E}$ within the humid rain forest of the tropical zone, $70 \mathrm{~m}$ above sea level and temperature range between $25^{\circ} \mathrm{C}$ and $26^{\circ} \mathrm{C}$, humidity $75-80 \%$ and annual rainfall ranging from $2250 \mathrm{~mm}$ to $2926 \mathrm{~mm}$. (Wikipedia , November 2016)

\subsection{Experimental Birds and management}

One hundred and twenty (120) Anark breed of broiler birds between 150 to $160 \mathrm{~g}$ in weight were purchased from a local vendor at Abak in Akwalbom State. Nigeria.The birds were vaccinated with intraocular vaccine against new castle disease at day old. Glucose was administered to the day old chicks (DOC) on the first day to make up for energy loses during transportation. On the subsequent days, vitamins and other medication were administered. The general weather condition was noted and temperature was adjusted accordingly. Vaccinations were given at the appropriate times.

\subsection{Feed Ingredients}

The feed ingredients used in the diets for the experiment are: yellow maize, soybean meal, wheat offal, fish meal, pro-vitamin A cassava (yellow), palm oil, vitamin premix, methionine, lysine, bone meal and common salt. All these ingredients except the pro-vitamin A cassava were procured from commercial vendors in Abak, AkwaIbom State, Nigeria. The pro-vitamin A cassava (UMUCASS 36 variety) is procured from the AkwaIbom State University farm at IkotEkaideh, IkotUbo.The yellow maize and soybean meal were ground with grinding machine to size suitable for the consumption of the birds. The pro-vitamin A cassava were peeled and washed. The tubers were sliced into flat chips and dried on a concrete floor under the sun for 3 consecutive days (0gundu et al 2014).[15]. After, they were ground and bagged for feeding experiment.

\subsection{Experimental Diets}

Formulated diet one treatment which served as the control had $100 \%$ maize as its main energy source while treatmentstwo (2), three (3), four (4), contained a combination of maize and pro-vitamin A at $25 \%, 50 \%$, $75 \%$ substitution of maize with pro-vitamin A cassava respectively. Treatment five (5) had 100\% pro-vitamin A cassava as the main energy source. The diets were iso-nitrogenous with $20 \%$ crude protein for poultry finisher

\subsection{Feeding experiment}

The one hundred and twenty day old birds were fed with commercial feed for four weeks before placingthem on the 5 experimental diets. They were randomly selected according to their weights in such a way that the average weight in each treatment is almost the same..The birds were fed ad lithium with adequate supply of water througout the experiment. Feeding and watering were carried out between the hours of 8.00 and 10.00 am each day.

\subsection{Data Collection and Analysis}

Records on daily feed intake were taken every morning by obtaining the difference between the quantity of feed taken the previous day and the quantity remaining. The birds were weighed at one day old and atthe commencement of the experiment (4 weeks). Subsequent weights were taken weekly.

\subsection{Statistical analysis}

The data collected were subjected to analysis of variance using statistical package for social sciences, version 20. One way analysis of variance (ANOVA) was used for comparison of the means. Differences between means were considered to be significant at $\mathrm{p}<0.05$ using the Duncan Multiple Range Test.

\subsection{Proximate analysis}

The moisture, dry matter, ash, crude fibre and lipid contents of the cassava varieties were determined using the AOAC (1990) [16].

\subsection{Carotenoid analysis}

The carotenoid content of the fresh cassava samples was determined using the method of Rodriguez-Amaya and Kimura (2004) [17].

\subsection{Cyanide analysis}

The residual cyanide levels of the flours of the cassava varieties were determined using the alkaline picrate method(Onwuka, 2005) [18]. 
III. Results And Discussion

Table 1. Nutrient composition of the experimental diets (Pro-vitamin A cassava-based diets)

\begin{tabular}{|l|l|l|c|c|c|}
\hline Ingredient & T1 $(0 \%)$ control & T2 $(25 \%)$ cassava & T3 (50\%) cassava & T4 (75\%) cassava & T5 (100\%) cassava \\
\hline Maize & 50.48 & 37.86 & 25.24 & 12.62 & - \\
Cassava & - & 12.62 & 25.24 & 37.86 & 50.48 \\
Soybean-meal & 12.77 & 13.23 & 14.00 & 14.68 & 17.83 \\
Fish meal & 8.01 & 8.32 & 8.83 & 9.28 & 13.42 \\
Wheat offal & 25.24 & 23.47 & 21.19 & 19.06 & 10.77 \\
Bone meal & 2.00 & 2.00 & 2.00 & 2.00 & 2.00 \\
Salt & 0.50 & 0.50 & 0.50 & 0.50 & 0.50 \\
Palm oil & - & 1.00 & 2.00 & 3.00 & 4.00 \\
Vitamin -premix & 0.50 & 0.50 & 0.50 & 0.50 & 0.50 \\
Lysine & 0.25 & 0.25 & 0.25 & 0.25 & 0.25 \\
Methionine & 0.25 & 0.25 & 100.00 & 100.00 & 0.25 \\
\cline { 2 - 7 } CP & 100.00 & 200.00 & 20 & 20 & 100.00 \\
CF & 20 & 6.30 & 6.58 & 6.70 & 20 \\
Metabolizable & 6.13 & 3.24 & 3.38 & 3.36 & 6.90 \\
energy(Kcal/g) & 3.18 & & & 3.29 \\
\end{tabular}

Table 2. Proximate analysis, vitamin A, residual cyanide of pro-vitamin A cassava (TMS 01/1368 or UMUCASS 36) yellow variety and yellow maize used in the experiment plus their vitamin A and cyanide content

\begin{tabular}{|l|l|l|}
\hline Nutrient & Pro-vitamin A Cassava (Yellow) & Yellow Maize \\
\hline Dry matter (\%) & 90.30 & 84.60 \\
Crude protein (\%) & 2.50 & 9.00 \\
Crude fiber (\%) & 3.6 & 2.20 \\
Ether extract (\%) & 1.12 & 3.80 \\
Ash (\%) & 2.28 & 1.50 \\
Vitamin A (ppm) & 2.60 & 2.40 \\
Residual cyanide (ppm) & 3.50 & 0.00 \\
\hline
\end{tabular}

Table 3. Summary of performance of broiler finishers placed on different levels of pro-vitamin A cassavabased diet

\begin{tabular}{|c|c|c|c|c|c|c|}
\hline & $\begin{array}{l}\text { Diet } 1 \\
(0 \%)\end{array}$ & $\begin{array}{l}\text { Diet } 2 \\
(25 \%)\end{array}$ & $\begin{array}{l}\text { Diet 3 } \\
(50 \%)\end{array}$ & $\begin{array}{l}\text { Diet } 4 \\
(75 \%)\end{array}$ & $\begin{array}{l}\text { Diet } 5 \\
(100 \%)\end{array}$ & SEM \\
\hline No. of birds & 24 & 24 & 24 & 24 & 24 & \\
\hline Average initial weight (g) & 818.00 & 820.00 & 81900 & 818.00 & 817.67 & 0.35 \\
\hline Average final weight $(\mathrm{g})$ & $2,120.00$ & $2,080.00$ & $1,961.00$ & 1940.00 & $1750.00^{\mathrm{b}}$ & 3.72 \\
\hline Average weight gain (g) & $1,302.00$ & $1,260.00$ & $1,142.00^{\mathrm{ab}}$ & $1122.00^{\mathrm{ab}}$ & $933.00^{\mathrm{b}}$ & 11.62 \\
\hline Average daily gain $(\mathrm{g})$ & $46.50^{\mathrm{a}}$ & $45.00^{\mathrm{ab}}$ & $40.79^{\mathrm{ab}}$ & $40.07^{\mathrm{b}}$ & $33.32^{\mathrm{b}}$ & 2.06 \\
\hline Average feed intake $(\mathrm{g})$ & $4,640.00$ & $4,530.00$ & $4,517.00$ & 4464 & 4446 & 6.19 \\
\hline Average daily intake $(\mathrm{g})$ & 165.71 & 161.79 & 161.32 & 159.43 & 158.79 & 2.42 \\
\hline Feed efficiency ratio & 3.56 & 3.59 & 3.95 & 3.98 & 4.77 & 0.44 \\
\hline Cost of production/bird ( & $1,040.56$ & 919.37 & $802.67^{\mathrm{ab}}$ & $684.77^{b}$ & $619.49^{b}$ & 31.65 \\
\hline Cost of production/kg weight ( $)$ & 490.83 & 442.00 & $409.32^{\mathrm{ab}}$ & $352.97^{\mathrm{b}}$ & $353,99^{\mathrm{b}}$ & .30 .00 \\
\hline Cost reduction per bird $(\%)$ & - & 11.65 & $22.86^{\mathrm{ab}}$ & $34.19^{\mathrm{b}}$ & $40.45^{\mathrm{b}}$ & 29.89 \\
\hline
\end{tabular}

Mean values in the same row with the same superscript show no significant difference $(\mathrm{P}>0.05)$.

The results on table 3 indicate that the birds placed on $0 \%$ level (the control) had slightly higher feed intake than others with $100 \%$ being the lowest. These differences however are not statistically significant $(\mathrm{P}>0.05)$. This similarity in feed intake could be as a result of close fiber and metabolizable energy content values of the diets as shown in table 1 . However the slight decreases observed with increasing levels of provitamin A cassava inclusion could be as a result of marshy texture of cassava-based diet and dustiness although reduced by the addition of palm oil. This agrees with findings reported by Ochetim (1991), [19].that marshy texture of cassava-based diets coupled with the lower bulk density are contributing factors to lower feed intake. This result also agrees with the finding of Tewe and Egbunike (1992). [13]that dustiness of cassava feedstuff can reduce feed intake in poultry which adversely affects productivity. Oke (1978). [20], had earlier observed that dustiness of cassava feedstuff causes irritation of the respiratory tract of the chickens unless the feed is pelletized or some oil is added. Palm oil was added in the cassava-based diets to reduce dustiness and increase metabolizable energy.

The average daily weight gain shown in table 3 shows that the weight gain by birds on $0 \%$ and $25 \%$ were significantly $(\mathrm{P}<0.05)$ higher than those on $100 \%$ but not significantly $(\mathrm{P}>0.05)$ higher than those on $50 \%$ and $75 \%$. Similarly the average daily weight gain of $50 \%$ and $75 \%$ are not significantly $(\mathrm{P}>0.05)$ higher than $100 \%$ nor each other. This significant difference could be as a result of the reduced feed intake of birds placed on $100 \%$ possibly due to slight dustiness and palatability. This agrees with the work of Ochetim (1991), [19], 
who found a decrease of $10 \%$ production in final body weight of broiler placed on $100 \%$ cassava-based diet $(1.91 \mathrm{~kg})$ with maize reference diet $(1.72 \mathrm{~kg})$.

The results on feed efficiency ratio indicate slight differences with $100 \%$ showing the highest value. These differences however were not statistically significant $(\mathrm{P}>0.05)$. This shows that all the birds in different treatment diets performed almost similarly.This could be as a result of iso-nitrogenous, almost iso-caloric and close fibre content of the diets which allowed the birds to have equal nutrients and fed similarly due to their age as broiler finisher. This could also be due to drastic reduction or elimination of the ant-nutritional and depressive factors of the cyanogenicglucoside, linamarin and lotaustralin in form of hydrogen cyanide $(\mathrm{HCN})$ to a low and non-toxic level (3.50ppm) by sun drying. This compares with the findings of Eleazu and Eleazu (2012), [5], in the six elite pro-vitamin A cassava varieties including the one used in this experiment (UMUCASS 36 yellow) which ranged from 2.24 to 3.40ppm This observation agrees with Tewe and Egbunike (1992), [13]; that the limitation of cassava and its products for livestock feeding due to the presence of $\mathrm{HCN}$ is reduced considerably by sun drying and when cassava $\mathrm{HCN}$ is below $100 \mathrm{ppm}(\mathrm{mg} / \mathrm{kg})$, cassava flour can be safely incorporated into the livestock feed. The safe cyanide content of the cassava used also agrees with the work of Ogunduet al (2014),[15], who obtained $93.77 \%$ reduction of cyanide in cassava by sun drying for 3 consecutive sunny days reducing fresh cassava edible portion with $52.95 \mathrm{ppm} \mathrm{HCN}$ to $3.30 \mathrm{ppm}$. Literature has also shown that cyanide content of cassava roots less than $50 \mathrm{mg} / \mathrm{kg}$ is non-toxic (Delangeet al 1982), [21]) and will not decrease performance. Any residual cyanide would have been converted to thiocyanate $(\mathrm{SCN})$ by rhodanase enzyme in the liver using sulphur from sulphur containing amino acids, methonine, lysine, cystene bringing the cyanide that would have caused depression to a negligible or zero level This rhodanese activity has earlier been expressed by Tewe and Egbunike (1992),[13]. Eleazu and Eleazu (2012), [5].

The cost of production in table 3 at the prevailing cost of all input shows that the cost of production of birds on maize-based diet is significantly higher $(\mathrm{p}<0.05)$ than that of $75 \%$ and $100 \%$ The cost reduction of $30.19 \%$ and. $40.46 \%$ were obtained from birds on $75 \%$ and $100 \%$ respectively.. Birds on $25 \%$ and $50 \%$ are inbetween with cost reduction of $11.65 \%$ and $22.86 \%$ respectively. The cheaper cost of production by birds on cassava-based diets could be as a result of the cheaper cost of pro-vitamin A cassava tubers compared to maize This result agrees with the work of Ochetim (1991), [19] who reported that cassava based diet was cheaper than maize-based diet with $30 \%$ reduction in cost with 'sweet cassava' variety

There was no incidence of mortality and disease outbreak among all the treatment diets throughout the experimental period ( 8 weeks) showing that pro-vitamin A cassava properly sundried and balanced in nutrients provided a healthy performance for broiler finishers comparable to maize based diet. This is an agreement with other workers who have used other varieties of "sweet" cassava(Ochetim (1991) [19]), who used cassava root and Ngikiet al 2012, [22].who used a combination of cassava root and leaf meal

\section{Conclusion}

This experiment has shown that pro-vitamin A cassava can be used to replace maize for broilers up to $75 \%-100 \%$ without any depressive effect. Despite the reduction in final body weight, the attractive economic value obtained using pro-vitamin A cassava-based diet in place of maize could be compensatory and may be justified. This experiment has also shown that processing cassava root chips by adequate sun drying for at least 3 consecutive sunny days will detoxify the cassava cyanogenicglucoside and reduce the toxic hydrogen cyanide $(\mathrm{HCN})$ to a non-toxic level that will not cause any depression in feed intake and general performance of the broiler finisher.

[1]. Tanumihardjo S. A. Food based approaches for ensuring adequate vitamin A nutrition. Comp Rev Food Sci Food safety $7:(2008) 373-81$

[2]. FAO.. The state of food security in the world .Food and Agricultural organization, Rome, Italy, (2003) ISBN 13: 9789251049860, page: 36.statistical database. Rome, Italy. FAO website.www.fao.org.

[3]. Julie A, Montagnac, Christopher R. Davis, and Sherry A. Tanumihardjo.Nutritional value of cassava for use as a staple food and recent advances for improvement.Journal Comprehensive Reviews in food science and food safety. 8,2005, 181-192.

[4]. Bio cassava plus .http://bio cassavaplus.org 2005

[5]. Eleazu C. O and Eleazu K. C Determination of the proximate composition of carotenoid, reducing sugars and residual cyanide levels of flours of 6 new yellow and white cassava (Manihotesculentacrantz) vanleties. America journal of food technology, 7: 2012, 642-649.

[6]. Olugbemi, T. S, Mutayoba S. K. and Lekule F. P. Effect of moringa (moringaoleifera) inclusion in cassava based diets fed to broiler chickens. InternationalJournal of poultry science 9(4), 2010,363-367.

[7]. Enyenihi, G. E. Udedibie, A. B. I. Akpan, M. J. ObasiO. L. and Solomon, I.P. Effect of 5 hours wetting of sundried cassava tuber meal on the hydrocyanide content and dietary value of the meal for laying hens. Asian journal of Animal Veternary Advances. 4:2009,326-331

[8]. Omole, T. A. and Eshiet, E.. Additions of methionine to cassavabased rations for rabbits. In progress report on the use of cassava as animal feed in Nigeria. Submitted to International Development Research Centre.IDRC, Ottawa, Canada.1996.

[9]. 9. Reveron, R. and Rodriquez, H..Cassava in ruminant nutrition in seminarion national de yucca.MarucayVenozuela. Revista de la aculted de AgronomiaAlcance.1982,613-624 
[10]. Tulem, C. C, Njike, M. C. Ikurior, S. A. and Ehiobu, N. G. Replacement of maize with cassava root meal/brewer feast slurring in thediets of broilers. Proceedings of the $30^{\text {th }}$ Annual Conference of Nigeria society for Animal production (NSAP).Universityof Nigeira, Nsukka, 2005,183-185.

[11]. Conn E. E' CyanogenicGlucosidesJ. Agric. Fed. Chem. 519-526Symposium of the international society for tropical cropsAfricaBranch IDRC 221C, 1981,25-33

[12]. Ikediobi, C.O. onyia,G. O.C and Eluwah, G.E. A radid and inexpensive enigmatic assay for total cyanide in cassava (Manihotsculentacrantz) and cassava products. Agric.Biol. chem. 44;1980,2803-2809.

[13]. Tewe, O. O., and Egbunike, G. N. Ultilzation of cassava in non-ruminant livestock feeds FAO Rome Italy, 1992.

[14]. ChiomaI Harbor and E. C. Ogundu. Effect of processing on cyanide Reduction in Different Cassava products.Nigeria journal of Biochemistry and Molecular Biology 24 (1),2009,35-37.

[15]. Ogundu E. C.,Okoh P. N., Ikediobi C.O: Effect of enzyme and non-enzyme processing on total detoxitication of cassava cyanogenicglucoside,linamarin for human food and Animal feed. Researchjournal's, Journal of Agriculture 1:[4),. 2014,2-8

[16]. AOAC, Official Methods of Analysis. 13th Edn., Association of Official Analytical Chemists, USA., 1990, $233-234$.

[17]. Rodriguez-Amaya, D.B. and M. Kimura, HarvestPlus Handbook for Carotenoid Analysis. International Food Policy Research Institute (IFPRI), Washington, DC., 2004, 34-36.

[18]. Onwuka, G.I., Food Analysis and Instrumentation: Theory and Practice. 1st Edn.,Napthali Prints, Surulere, Lagos-Nigeria, 2005, $140-160$.

[19]. Ochetim. The use of cassava in broiler feeding in the South Pacific.Asian journal of Agriculyural Science,4(3),1991,241-244.

[20]. Oke. O .L. Problems in the use of cassava as Animal feed. AnimalfeedScienceandtechnology3, 1978, 345-380.

[21]. Delange F. F., B. Iteke and A. M. Emmans. Nutritional Factors Involved in the Goitrogenic actions of Cassava.International Development Research centre, Ottawa, Canada. ISBN 13: 9780889363151:1982, 100.

[22]. Ngiki Y. C:,Igwebuike, J. C.,Moruppa S.M. Effects of replacing maize with cassava root-leaf meal mixture on the performance of Broilers chicks. International Jourray of science and Technology. 3[6]:(2014) 352-360. 